\title{
VVAK DOET MAJEURE AANKOPEN DANKZIJ STICHTING 400 JAAR VOC
}

\author{
Eymert van Manen - Secretaris Stichting 400 jaar Amsterdam - \\ Verenigde Oost-Indische Compagnie
}

Het was niet lang na de Amsterdamse Eurotop in 1997 dat toenmalig burgemeester Schelto Patijn erop werd gewezen dat in 2002 aandacht besteed zou moeten worden aan het feit dat het in dat jaar 400 jaar geleden zou zijn dat in Amsterdam de Verenigde Oost-Indische Compagnie werd opgericht.

Patijn pakte dit idee enthousiast en actief op: er werd een plan op hoofdlijnen geschreven dat ten stadhuize ambtelijk goed viel, en bij bezoeken aan Den Haag wist Patijn ook in kringen van parlement en ministeries positieve reacties op te wekken.

Het voornaamste project dat gezamenlijk in Amsterdam en Hoorn werd ontwikkeld was het internationale Upstream, een route langs beeldende kunstwerken, die in situ op bekende en onverwachte VOC-locaties waren gerealiseerd door enerzijds kunstenaars uit voormalige VOC-landen, anderzijds Nederlandse kunstenaars. In totaal deden circa veertig vooraanstaande kunstenaars mee, die in de gekozen opzet vrij waren hun interpretatie te geven van het Nederlandse VOCverleden. Resultaat was een indrukwekkende kunstroute door Amsterdam en Hoorn, die ook in de internationale kunstpers opzien baarde. Naast Upstream werd onder meer de replica van de Duyfken die uitgezwaaid door Prins WillemAlexander vanuit Australië was komen zeilen, feestelijk op de Amstel ontvangen, werden in de vaste opstelling in het Amsterdams Historisch Museum VOC-accenten aangebracht, vonden VOC-rondleidingen in de stad plaats, werd op de Nieuwmarkt een VOC-markt en -festival gehouden, en werd door de Kamer van Koophandel een VOC Captain's Dinner georganiseerd voor het bedrijfsleven.

De Stichting 400 jaar Amsterdam - Verenigde Oost-Indische Compagnie die dit alles initieerde kende een bestuur van vooraanstaande Amsterdammers, die daartoe waren opgeroepen door de onvermoeibare Jaap Rost Onnes. Wat dat bestuur zich pas geruime tijd na afloop van het project realiseerde, was dat ten gevolge van het vervallen van een forse schadeclaim van een Zuid Afrikaanse kunstenares, een bedrag resteerde waarmee ruim 10 jaar later aan de VVAK twee fantastische schenkingen konden worden gedaan, namelijk het grote Amsterdam-bord dat in dit nummer wordt besproken door Jan van Campen, (pag. 42 e.v.) en 13 unieke tekeningen - waaronder een verrassende tekening van Deshima - waarover $\mathrm{u}$ binnenkort meer zult kunnen lezen. 